\title{
In memoriam Ljubinku Pušiću (1952. - 2016.)
}

Ljubinko Pušić, redovni profesor urbane sociologije i sociologije okruženja Filozofskog fakulteta u Novom Sadu, preminuo je 14. juna 2016. godine, u 64. godini Života.

Rođen je 12. oktobra 1952. u Novom Sadu. Diplomirao je na Arhitektonskom fakultetu u Beogradu 1976. godine i magistrirao na Katedri za urbanizam novosadskog Fakulteta tehničkih nauka 1981. Doktorsku disertaciju na temu Urbanistički razvoj gradova u Vojvodini u 19. i prvoj polovini 20. veka odbranio je 1985. godine na Arhitektonskom fakultetu u Beogradu, pod mentorstvom Bogdana Bogdanovića. Nakon diplomiranja radio je jedanaest godina u Zavodu za urbanizam Novog Sada, nakon čega se preusmerava na akademsku karijeru. Na Tehničkom fakultetu „Mihajlo Pupin“ u Zrenjaninu biran je za docenta 1987. godine i za vanrednog profesora 1992. godine. Tada prelazi na Odsek za sociologiju Filozofskog fakulteta u Novom Sadu, gde je 1997. godine izabran za redovnog profesora. Tu se posvećuje zasnivanju i razvoju prostorno senzitivnih socioloških disciplina, prvo sociologije grada a nešto kasnije i sociologije okruženja. Kao postdoktorant na TU Delft u Holandiji 2003. godine radio je na integraciji ove dve sociološke discipline kroz istraživanje kulturnog konteksta urbane održivosti.

Bio je predsednik Udruženja sociologa Srbije i Crne Gore, član Odeljenja za društvene nauke Matice srpske i dugogodišnji član Akademije arhitekture Srbije. Zahvaljujući jedinstvenom sklopu znanja, afiniteta i posvećenosti, Ljubinko Pušić je uspeo da proizvede sistematizovan naučni opus koji se sastoji od deset knjiga i preko stotinu naučnih radova. Među njima se posebno ističu temeljne teorijsko metodološke studije koje su nastale u funkciji konstituisanja pojedinih disciplina ali i one društveno angažovane zahvaljujući kojima će u široj javnosti ostati zapamćen kao vrstan poznavalac, hroničar i neumorni kritičar sveukupnog stanja naših gradova. Objavio je Grad, društvo, prostor (1997.) koji su recenzenti opisali kao najbolji udžbenk iz sociologije grada do tada objavljen na srpskom i hrvatskom jeziku, a 2015. godine izlazi i njegovo drugo izdanje. Sociologiju grada i sociologiju okruženja dublje integriše u knjizi Održivi grad: ka jednoj sociologiji okruženja (2001.) a u 2014. godini objavljuje i Sociologiju okruženja, čime postavlja temelje za dalji razvoj ove discipline u Srbiji. Dugogodišnje interesovanje za istoriju grada objedinio je u knjizi Grad: Znaci vremena (1991.) gde je zapisao kako se „istinsko suočavanje sa gradom ne može dogoditi drugačije nego pažljivim i upornim razgrtanjem nagomilanih slojeva prošlosti“. U Čitanju grada (1995.) posvetio se istorijsko-institucionalnoj analizi Praga, Rima i nekoliko američkih gradova a u Pisanju grada (2007.) beležio je i komentarisao crtice iz urbane svakodnevice različitih gradova - od Haga do Beograda. O svom rodnom gradu Novom Sadu pisao je u knjizi Grad bez lica (2009.). 
Bio je veliki erudita, a njegova znanja o gradovima, uveliko su nadilazila granice pojedinih naučnih disciplina. Ukoliko bi se morao izdvojiti jedan, ključan doprinos Ljubinka Pušića urbanoj sociologiji u regionu, to bi upravo mogla da bude ta izvanredna širina pogleda na grad koja se danas sve više gubi usled specijalizacije i fragmentacije istraživačkih interesovanja u ovoj oblasti.

Profesor Pušić uz svoj veliki angažman u akademskom radu vrlo je angažirano radio i na brojnim projektima u regiji, te je kolegijalnim i profesionalnim pristupom posebno doprinio uspostavljanju ponovne suradnje između Srbije i Hrvatske, odnosno njihovih filozofskih fakulteta i instituta, koja je od devedesetih godina 20. st. bila zaustavljena. Nesebično se odazivao i sudjelovao u mnogim konferencijama, skupovima i okruglim stolovima koji su proučavali društvene i urbane promjene nastale u tranziciji u Novom Sadu, Beogradu i Zagrebu, proučavajući ih kritički, ali i čineći ih komparativnima i nadasve ističući brigu za građane i njihovu kvalitetu života, koja je, kako je znalački znao istaknuti, postala sve ugroženija. Veliki je doprinos dao i recenzirajući mnoge zajedničke publikacije i zbornike radova nastale kao plod zajedničke suradnje, posebice s Institutom za društvena istraživanja u Zagrebu, čime je zadužio i hrvatsku urbanu sociologiju i njene istraživače. Svojim je profesionalnim radom te prvenstveno prijateljskim i otvorenim pristupom nerijetko izazivao iskreno divljenje i stoga je njegov prerani odlazak nemjerljiv gubitak za zajedničku nam sredinu.

Ana Pajvančić - Cizelj

Filozofski fakultet, Univerzitet u Novom Sadu

Anđelina Svirčić Gotovac Institut za društvena istraživanja u Zagrebu 